\title{
Impact of The Advancement of Functional Value on Digital Media for Students in the Industrial Era 4.0
}

\author{
Silvia Devi, Lady Khairunnisa Adiyani, Ohara Cristhoper Panggabean, Linda Wulanika \\ silvia.devi-2020@fib.unair.ac.id; lady.khairunnisa.adiyani-2020@ fib.unair.ac.id; \\ linda.wulanika-2020@fib.unair.ac.id; ohara.cristhoper.panggabean-2020@ fib.unair.ac.id
}

Corresponding Author: Silvia Devi/silvia.devi-2020@fib.unair.ac.id

Faculty of Humanities Campus B Universitas Airlangga, Jalan Dharmawangsa Dalam

Surabaya, Indonesia. 60286. Phone: 031-5035807 Fax: 031-5035807

\begin{abstract}
The problem of the functional value advancement on digital media resulted in increased competitiveness in the face of the current industrial era 4.0. Prospective professionals are also required to have knowledge and abilities that can compete in the current industrial era 4.0. The new chapter of industry 4.0 also has a significant impact, especially in work. One of them is the number of abilities or skills that must be owned by the community, especially students, to get a job. However, many students find it challenging to find work in today's digital and industrial age. They also have minimal experience and knowledge in utilizing digital media. The purpose of this research is to find out more about the reasons for utilizing the advancement of the functional value of digital media along with the impact and results of the advancement of the functional value of digital media for students in facing the current industrial era 4.0. The authors used questionnaires, observations, and online literature studies to obtain the data needed and used them as references by comparing, analyzing, and matching before completing the study. The study used Miles and Huberman qualitative data analysis. The data obtained will be analyzed descriptively qualitatively. The results showed that in the research sample, namely students of the Faculty of Cultural Sciences batch 2020 Universitas Airlangga, the advancement of the functional value of digital media had had a positive impact and results. Both in increasing the skills needed in the competition of the industrial era 4.0 and obtaining information and opportunities for students to participate in internships, volunteers, and others that support the improvement of experience.
\end{abstract}

Keywords: Industry 4.0, Students, Digital Media, Values 


\section{INTRODUCTION}

\section{Background}

The digital era and industry 4.0 today have substantially impacted work. Industrial Revolution 4.0 is a comprehensive transformation of the overall aspects of production in the industry by merging digital technology and the internet with conventional industry (German Chancellor Angela Merkel, 2014). The COVID-19 pandemic also affects everyone, especially students, to prepare themselves as well as possible because the world of work is increasingly fierce and requires more skills and knowledge. Previously, people were not too accustomed to use digital media to benefit work and professionalism. However, since the COVID-19 pandemic and the industrial era 4.0 began, everyone has been required to use digital media. New media is also called new digital media.

Digital media is a medium whose content is in the form of a combination of data, text, sound, and various types of images stored in digital format and disseminated through cablebased networks of broadband optics, satellites, and microwave systems (Flew, 2008, 2-3). The entry of society in the digital and industrial era 4.0 provides convenience with various applications, sites, or social media that we can use to improve work relationships, knowledge, and skills that the community, especially students, need to get a job. The occurrence of very significant changes brings many new qualifications and requirements commonly used in the recruitment process in selecting a job vacancy. Therefore, students must also adapt and take advantage of the advancement of the functional value of digital media available.

The younger generation can potentially use digital media to help build quality human resources (HR). Quoted from the World Economic Forum, there are ten skills or skills that must be mastered to be able to compete in the era of the industrial revolution 4.0, namely complex problem solving, critical thinking, creativity, people management, coordinating with others, emotional intelligence, judgment, and decision making, service orientation, negotiation, and cognitive flexibility (Alex Gray. The 10 skills you need to thrive in the Fourth Industrial Revolution, www.weforum.org/agenda/2016/01/the-10-skills-you-need-to-thrive-in-thefourth-industrial-revolution/. Retrieved November 20, 2021). The availability of various applications, sites, and social media such as LinkedIn, Vokraf, Coursera, and elearn.id certainly makes it easier for students to make this happen. Students can conduct training, learning activities and expand online relationships flexibly to help prospective professionals in the world of work improve their knowledge and expertise.

Informal learning and training networks play a substantial role in skills development for professionals working, particularly in today's industrial 4.0 era. Students who have limited access to learning can take advantage of various digital media services and features as an alternative solution. So, it is easier to map out their learning path. Therefore, students must know why digital media can increase knowledge and prepare students to become professionals in this industrial era 4.0.

\section{Research Reference Gap}


Previous research on the utilization of the advancement of the functional value of digital media has been published in the form of a scientific article entitled "Efektivitas Pemanfaatan Canva sebagai Media Pembelajaran Daring” (Nut Mila, Nuralamsyah, Andi Naila Quin A. A., Nur Arisah, \& Muhammad Hasan, 2021). This research discusses digital media results and effectiveness, namely the Canva application as an online learning medium for students. However, this study examines more profoundly and specifically related to the effectiveness and benefits of other digital media for students, significantly to improve the quality of human resources (HR) in competition in the current industrial era 4.0.

From the research described earlier, it can be known that there has been no research that discusses the impact and results of utilizing the functional value of various digital media for students, significantly as a step to improve the quality of human resources (HR) students to face stiff competition in the current industrial era 4.0. Therefore, researchers are interested in researching the impact and results of using digital media for students in the current industrial era 4.0.

\section{Research Objectives}

The purpose of this study is as follows:

a. to find out the background of the utilization of the advancement of the functional value of digital media for students in the industrial era 4.0.

b. knows the impact and results obtained by students after utilizing the advancement of the functional value of digital media in the industrial era 4.0.

Regarding previous research, survey results, data observation, and research literature studies are expected to provide complete information and knowledge. So that it can be accepted and understood easily by the community. In addition, the results of this study also aim to encourage the community, especially students, to take advantage of the advancement of the functional value of digital media in improving the quality of human resources (HR) to face stiff competition in the world of work in the current industrial era 4.0.

\section{Benefits of Research}

- Theoretical Benefits

The research results can be used as a foundation and reference in developing further utilization of the functional value of digital media. In addition, the results of this study can also be a plus in the source of scientific science.

- Practical Benefits

It can be an alternative solution in improving the quality of human resources (HR) of the community, especially students in the industrial era 4.0, increasing public understanding of the functions and benefits of digital media, and reducing the unemployment rate in Indonesia. 
In addition, this study can also improve researchers' knowledge and insights regarding the impact and outcomes of the advancement of the functional value of digital media in the current industrial era 4.0.

\section{Research Questions}

Previous research raises several questions to be a significant focus in this study, including:

1) Why does the utilization of the advancement of the functional value of digital media need to be done by students today?

2) What are the impacts and results obtained after utilizing the advancement of the functional value of digital media in this industrial era 4.0?

\section{RESEARCH METHODS}

\section{Types of Research Approaches}

The method used in conducting this research is a qualitative research approach. Qualitative research methods are research approaches that focus on a deep understanding of a problem being studied and usually use in-depth analysis techniques, where a problem is studied on a case-by-case basis because the nature of each problem will differ from the other.

According to Creswell in Sugiyono (2012), qualitative research approaches are divided into five types: phenomenological research, grounded theory, ethnography, case study, and narrative research. This research applies qualitative research of phenomenological research and grounded theory. In the phenomenological research method, data is obtained from participant observation through online surveys to find out the essential phenomena of participants. While in the grounded theory method, researchers conclude what is observed inductively, abstract theories about processes and actions based on the views of survey participants studied.

In addition to online surveys, qualitative methods used are literature studies, namely by conducting a review of books, literature, notes, and various reports related to the problem to be solved (Nazir: 1988). Researchers gather information relevant to the problem being studied.

\section{Data and Population Sources}

Data sources are all things that can provide information related to the data needed in a study. In this study, the data obtained by researchers was sourced from primary data and secondary data.

1) Primary Data 
According to Husein Umar (2013: 42), primary data is obtained from the first source, either from individuals or individuals, such as the results of interviews or questionnaires that researchers usually do. In this study, researchers obtained primary data by carrying out questionnaires. Researchers created a questionnaire through the Google Form platform, then asked respondents to fill out a questionnaire containing several questions related to the information needed in the study.

2) Secondary Data

According to Wardiyanta in Sugiarto (2017: 87), secondary data information is obtained not directly from the source but from a third party. In this study, researchers obtained secondary data from the literature study results. Researchers looked for journals related to the study, such as journals on digital media as an online learning medium, to find additional information relevant to the study.

The population is an important thing that must exist because it is used to answer the problems contained in the research. Sugiyono (1997: 57) stated that population is a generalization area consisting of objects or subjects of specific characteristics determined by the researcher to be studied and then concluded. Thus, from this understanding, the specified population must be appropriate - able to answer existing problems. This study's population is set in the Faculty of Humanities students, Airlangga University batch of 2020.

\section{Data Collection Techniques}

Data is a unit of media recorded information distinguished from other data, analyzed, and relevant to a particular program. Data collection is a systematic and standardized procedure for obtaining the necessary data. To collect the researcher's data, the authors used the primary data collection method of observation and questionnaire and secondarily the literature study, with the following details:

a. Method of Observation (Observation)

The observation method is systematic observation and recording of the symptoms seen in the object of the study. Observation is a data collection method that uses observations of research objects that can be carried out directly or indirectly. We use non-participant observations so that they are done without the direct involvement of researchers as observers. So, in this study, the author made observations of our target, namely Airlangga university students. We made observations to collect some facts related to our research as objective evidence, such as through posts or content shared by students on social media related to the results obtained after utilizing the advancement of the functional value of digital media in this industrial era 4.0.

b. Questionnaire Method

A questionnaire method is a list that contains a series of questions about a problem or field to be examined. To obtain the data, questionnaires are distributed to respondents (people who answer questions asked for research purposes), especially in survey research. In this case, 
the author makes written questions that the respondent/sample answered. The form of the questionnaire that we use is open and closed angle. The open questionnaire is a questionnaire where the problems initially use multiple-choice techniques, or there is already an answer choice, and continued with a closed questionnaire in the form of essay questions so that respondents can develop answers. Questionnaire techniques are used to determine the level of utilization of the advancement of the functional value of digital media by students in this industrial era 4.0.

c. Literature Studies

Literature studies collect data by studying and reading literature related to the research problem. This literature study is not directed to the research subject because this method analyzes documents made by others who have researched topics related to the level of utilization of the advancement of the functional value of digital media by students in the industrial era 4.0. As this research, we use literature studies in the form of previous research on the utilization of the advancement of the functional value of digital media has been published in the form of a scientific article entitled Effectiveness of The Use of Canva as an Online Learning Medium (Nut Mila, Nuralamsyah, Andi Naila Quin A. A., Nur Arisah, \& Muhammad Hasan, 2021). This research discusses digital media results and effectiveness, namely the Canva application as an online learning medium for students.

\section{Data Analysis Techniques}

The data analysis technique is a process for grouping, making comparisons, and identifying the similarities and differences of data to find helpful information in a study. We used Miles and Huberman qualitative data analysis techniques in this study. According to both, the qualitative data analysis process is carried out in three stages, namely:

\section{A. Data Reduction}

Data reduction is the stage of reducing or simplifying data to be under the needs so that it is easy to get information. The data reduction stage is a process of selection, simplification, and abstraction. In this study, researchers reduced the data by making selections, making summaries or brief descriptions, and classifying patterns by making transcripts, for example, grouped from data that are very important, less important, and not necessary. This data is then processed to be more straightforward by the needs of research to represent all the data that has been obtained.

\section{B. Presentation of Data}

After completing the reduction stage, it goes to the data presentation stage. At this stage, the researcher presents data that has been reduced in the previous stage. The form of data presented in this study is a form of the diagram to ensure that the data obtained can be more easily understood by others. In addition, researchers also provide explanations so that readers can more easily capture the information presented. The process of presenting data is required in qualitative data analysis to present or display data neatly, systematically, arranged with 
organized relationship patterns so that this data is no longer raw but is already in the form of a conclusion.

C. Withdrawal of Conclusions

The next stage that will be done in qualitative data analysis is the withdrawal of conclusions. Researchers' compiled data will be grouped, presented, and drawn conclusions. This conclusion is presented in the research report and placed in the closing section. The process of drawing new conclusions can be done when all varied data is simplified, compiled, or displayed using specific media.

\section{RESULTS OF RESEARCH AND DISCUSSION}

\section{Research Results}

The study results contain research results relevant to the objectives of the final task. The data obtained from surveys conducted online through Google Form, observations conducted online through respondent upload content and library studies that authors gradually conduct to get appropriate and genuinely relevant data. The data obtained is then analyzed further. As an initial stage, data is grouped based on the source, namely primary and secondary data.

1. Primary data

Primary data is data obtained online on research objects, namely students of the Faculty of Cultural Sciences Force 2020 Universitas Airlangga who became a research sample. Researchers analyzed the reasons and impacts generated by the sample after utilizing the advancement of digital media's functional value in the current industry 4.0. From these analyses and observations, researchers get the necessary data that can be said to be primary. These data include:

1) The sample uses digital media.

2) Frequency of samples in using the previously mentioned digital media.

3) The reason the sample uses digital media.

4) What are the impacts and results obtained by the sample after utilizing the progress of the functional value of digital media in the current industrial era 4.0.

2. Secondary Data

Secondary data is data obtained indirectly to support research. The secondary data was obtained from library studies from various books, journals, and global internet media. Secondary data collected to support the study include:

1) Relevant previous research results related to the benefits of progressing the functional value of digital media. 
2) Theories - theories related to research that have been outlined in the literature review.

3) Material on the advancement of the functional value of digital media and the world of work in the current industrial era 4.0.

\section{Analysis of Research Results}

Research results were obtained and grouped according to the data source then analyzed further. After collecting data from research targets that have been established through the process of sharing questionnaires and observations conducted online to the research population, researchers have collected the necessary data to support the research activities carried out. Of the twelve questions given through the questionnaire shared, the following descriptions and diagrams of the results of answers from the target respondents have been obtained.

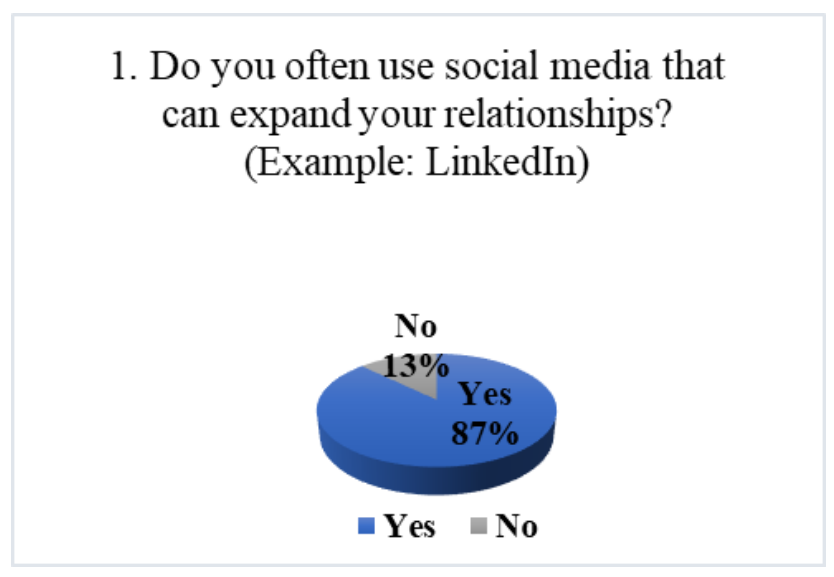

Figure 2.1 Diagram of Survey Results

Based on the data displayed in figure 2.1, it is seen that $87 \%$ or 57 out of a total of 70 samples use digital media applications or social media such as LinkedIn to expand relationships in the current industrial era 4.0. The sample used the app to communicate and analyze the conditions of the world of work in the industrial era 4.0 by looking at some of the posts shared by recruiters.

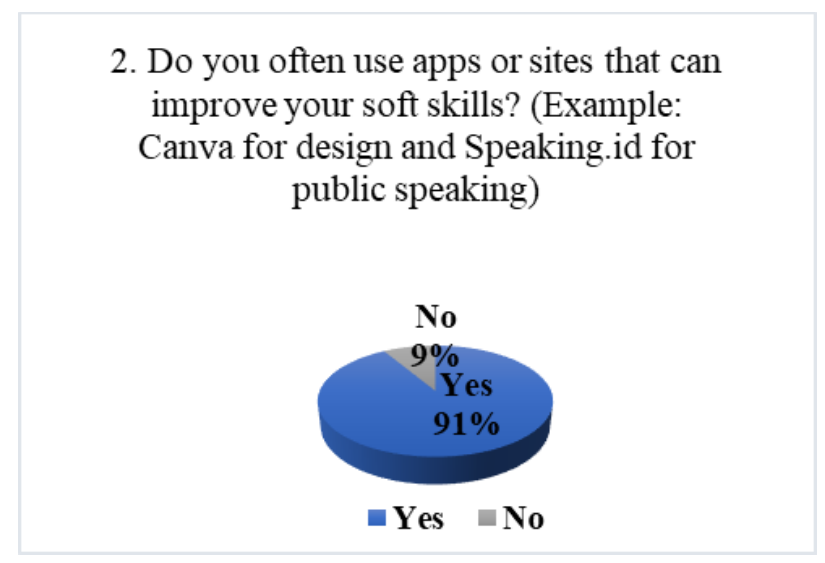

Figure 2.2 Diagram of Survey Results 
Based on the data displayed in figure 2.2, it is seen that $91 \%$ or as many as 64 out of 70 samples using digital media (applications, sites, or other digital media) such as Coursera and Canva as a means of developing skills that are needed in the world of work in the industrial era 4.0 today. Samples use these applications to learn and develop their abilities in various fields. Examples are design, authorship, public speaking, digital marketing, and other fields.

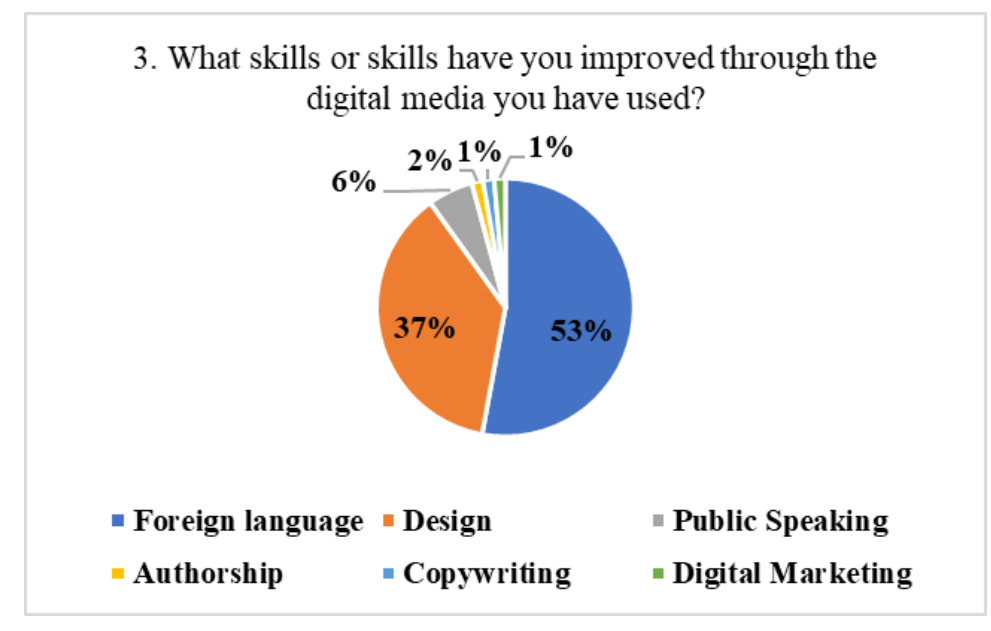

Figure 2.3 Diagram of Survey Results

Based on the data shown in figure 2.3, it appears that 53\% or as many as 36 samples have improved their expertise in foreign languages, then $37 \%$ or as many as 26 samples have increased their expertise in the field of design by $6 \%$ or three samples have increased their ability to public speak, by $2 \%$ or two samples have improved their ability in the field of authorship, and $2 \%$ or two samples have increased their expertise in copywriting and digital marketing. Samples use digital media (applications, sites, or social media) such as Coursera and Canva to develop skills needed in the world of work in the industrial era 4.0 today. They use these applications to learn or develop their various fields, such as design, authorship, public speaking, digital marketing, and other abilities.

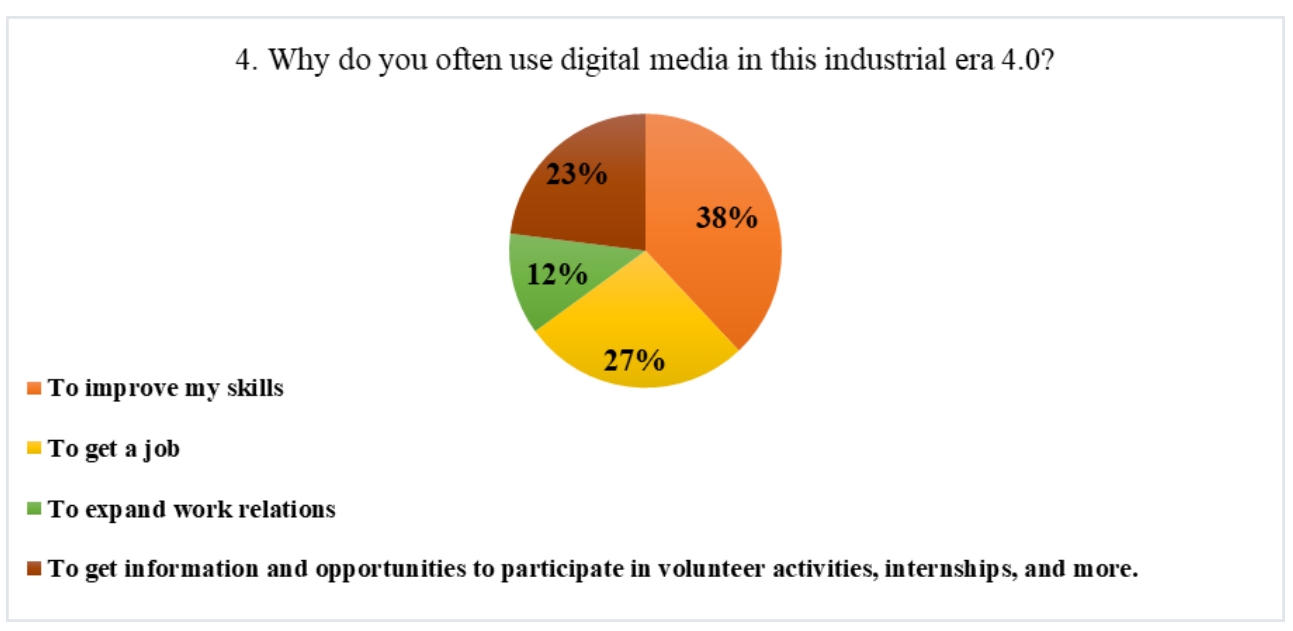

Figure 2.4 Diagram of Survey Results

Based on the data presented in figure 2.4, it is seen that there are four reasons behind respondents using various digital media, whether applications, sites, or social media, in the 
current industrial era 4.0. These reasons are improving your skills, getting job openings, finding job relationships, and getting information about user activities such as webinars and internships. This reflects the confidence and expectations of students to be productive and be able to compete in the world of work in the current industrial era 4.0 by utilizing the advancement of the functional value of digital media.

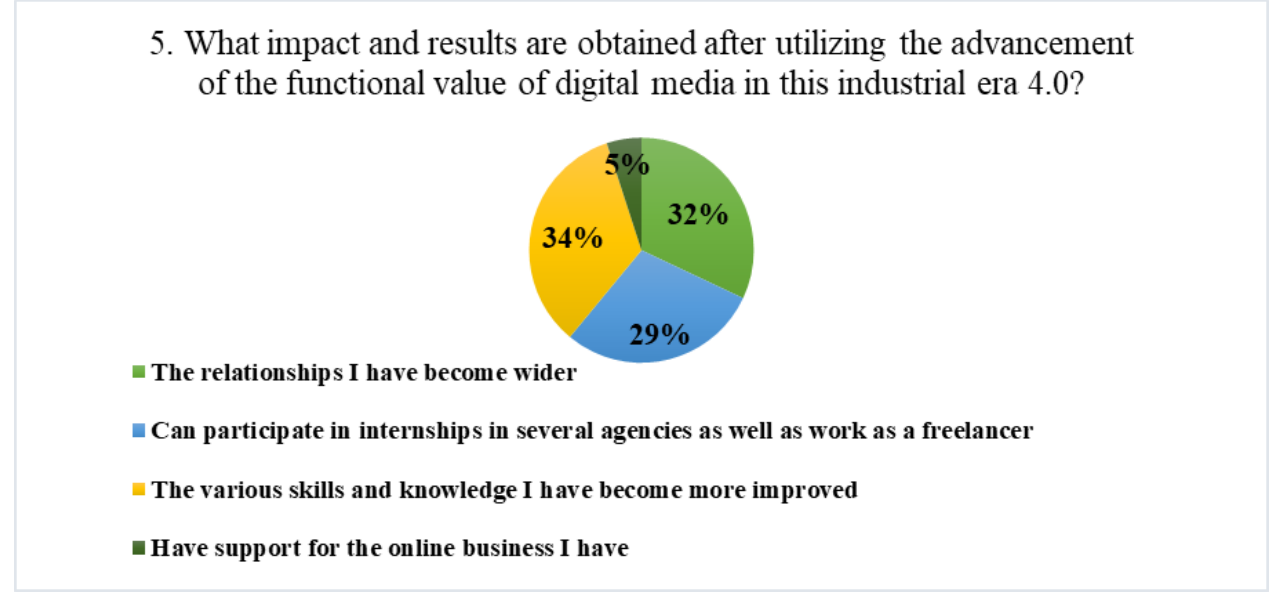

Figure 2.5 Diagram of Survey Results

Based on the data displayed in figure 2.5, it is known that the sample obtains four impacts and results after utilizing the progress of the functional value of various digital media by using applications, sites, and social media in the current industrial era 4.0. The results showed that 22 samples managed to improve or expand relationships, 20 samples managed to get internship and work opportunities, 24 samples managed to improve their expertise in copywriting, digital marketing, and design, and four samples managed to get support in the form of promotion and market improvement for online business conducted. This is one proof that the impact and results felt by the sample from the improvement of the progress of the functional value of digital media in the industrial era 4.0 is classified as positive and very useful, primarily to support the dreamed career.

From the results of data collection techniques through literature studies, namely scientific articles entitled Effectiveness of Canva Utilization as an Online Learning Medium (Nut Mila, Nuralamsyah, Andi Naila Quin A. A., Nur Arisah, \& Muhammad Hasan, 2021), we made the article that one form of digital media is the application experiencing functional value advancements that have positive impacts and results. In addition, the theory and material we get from literature studies we have used in previous explanations to support the results of research and discussion that we have provided.

Based on the results of the data analysis, it can be concluded that most students use digital media to expand relations in the current industrial era 4.0. Expanding relationships through digital media will get more information about the world of work in the industrial era 4.0. Furthermore, most students also use digital media (applications, sites, or other digital media) such as Coursera and Canva to develop skills and expertise needed in the world of work in the current industrial era 4.0. They use these applications to develop their skills in various fields, such as design, authorship, public speaking, digital marketing, and other fields. 
The types of skills or expertise that have been improved through the digital media they use also vary. Like most students who have improved their foreign languages, they have increased their design, public speaking, authorship, copywriting, and digital marketing expertise. Students often use digital media in era 4.0 to improve their skills, get job openings, find job relationships, and get information about user activities such as webinars and internships. Thus, it can be known that the impact and results obtained from the advancement of the functional value of various digital media by using applications, sites, and social media in the current industrial era 4.0 are positive impacts and results to support the careers of students later.

\section{CONCLUSION}

\section{Conclusion}

With the existing and growing progress of the functional value of digital media today, students can take advantage of it to meet all kinds of needs and preparations that must be had before jumping into the world of work. The reason behind them to take advantage of the advancement of the functional value of digital media is to get helpful information about productive work and activities, get opportunities for internships and work, and improve their various skills in various fields that are currently needed in the competition of the industrial era 4.0 today. In addition, the impact and results obtained by students of the Faculty of Cultural Sciences Class 2020 are entirely positive.

Some of the impacts and results they get are increasing their expertise in various fields, getting opportunities to intern in several agencies, expanding their work relationships, and getting support for the business they are working on. The competition of the world of work in the industrial era 4.0 is becoming increasingly tight and high. So, with the known results and positive impact of the progress of the functional value of various digital media, it is expected to be one of the solutions to improve the quality of existing human resources. Thus, the community, especially students, will compete in the world of work in the current industrial era 4.0 .

\section{Research Limitation}

The limitation or weakness of this research lies in the research process. Researchers realize that there must be one or more weaknesses in a study. One of them is from a survey session. Sometimes the answers given by the informant do not match the researcher's question, or sometimes the researcher gives almost the same question but has a different meaning. Then, the informant replied with the same answer. To solve this problem, the researcher finally reascertained the answer that the informant gave and explained the intent of the researcher's question through the email address that the respondent had attached when filling out the questionnaire given. 


\section{Suggestions and Recommendations}

Based on the conclusions outlined above, some recommendations can be submitted.

1) For the Campus

As an educational institution, to improve the expertise and knowledge of students relevant to the needs of the current industrial era 4.0, there needs to be support from the campus to realize this through several informative activities. These activities can be seminars and workshops that explain and provide information about using digital media in the current industrial era 4.0 for students. Because the existence of these activities is expected to create graduates who have qualified human resources to compete in the world of industrial work 4.0 now.

2) For the Students

With the holding of informative activities on the results of the use of digital media in the current industrial era 4.0 for students by campus, it is expected that all students can improve their expertise, knowledge, and experience by utilizing the functional value of existing digital media so that graduates can compete for jobs in the current industrial era 4.0. In addition, students are also expected to experience the fear and lack of preparedness they feel because of their lack of knowledge, expertise, and experience.

3) For the Next Researcher

The researchers are then expected to pay attention to questionnaire questions given to informants when conducting the same type of research. The goal is not to repeat the error as it happened to the researcher when the survey process was conducted. 


\section{BIBLIOGRAPHY}

Davies, R. 2015. Industry 4.0 Digitalisation for productivity and growth.

Era Revolusi Industri 4.0. Jurnal Literasiologi. 3 (1):177-189.

Fadli M. R. 2021. Hubungan Filsafat Dengan Ilmu Pengetahuan Dan Relevansinya Di Era Revolusi Industri 4.0 (Society 5.0). Jurnal Filsafat. 31 (1):130-161.

Hennida, Citra., Aryani, K., Kinasih, S.E. 2021. The use of social media among Indonesia's Migrant Workers (IMWs). Masyarakat, Kebudayaan, dan Politik. 34(1):13-22.

http://www.europarl.europa.eu/RegData/etudes/BRIE/2015/568337/EPRS_BRI(2015)568337 _EN.pdf, Downloaded on November 28, 2021.

https://datareportal.com/reports/digital-2021-indonesia. Downloaded on November 23, 2021. https://eprints.uny.ac.id/18427/5/5.\%20BAB\%20III.pdf. Downloaded on Desember 1, 2021. https://journal.binus.ac.id/index.php/BECOSS/article/download/6070/3740/28896 https://raharja.ac.id/2020/11/08/data-primer/

Husein Umar. 2013. Metode Penelitian untuk Skripsi dan Tesis. Jakarta: Rajawali.

Jaya N.A. 2020. Filsafat Ilmu dalam IPTEK. 10.31219/osf.io/tfe85. PREPRINTS. URL: 10.31219/osf.io/tfe85.

Merkel, A, (2014). Speech by Federal Chancellor Angela Markel to the OECD Conference. http://www.bundesregierung.de/Content/EN/Reden/2014-02-19-0ecd-merkel-paris-en.html. Downloaded on November 11, 2021.

Miles, M. B. \& Huberman, M. (1992). Analisis Data Kualitatif. Jakarta: Penerbit Universitas Indonesia

Nazir. (1988). Metode Penelitian. Jakarta: Ghalia Indonesia.

Neugebauer, R., Hippmann, S., Leis, M \& Landherr, M (2016). Industrie 4.0-From the Perspective of Applied ReseachProcedia CIRP, Vol. 57, pp 2-7.

Nugroho P. A. 2019. Pengaruh Revolusi Industri 4.0 Terhadap Wajah Perpustakaan Perguruan Tinggi. Jurnal Perpustakaan Universitas Airlangga. 9 (2):63-66.

Nut Mila, Nuralamsyah, Andi Naila Quin A. A., Nur Arisah, \& Muhammad Hasa. 2021. Efektivitas Pemanfaatan Canva sebagai Media Pembelajaran Daring. http://prosiding.rcipublisher.org/index.php/prosiding/article/download/132/23. Downloaded on November 26, 2021.

Permatasari M.P., Endriastuti A. 2020. Pelatihan Pemanfaatan Media Sosial Sebagai Alat.

Rosnawati, Syukri A., Badarus Syamsi, Rizki A. F. 2021. Aksiologi Ilmu Pengetahuan Dan Manfaatnya Bagi Manusia. Jurnal Filsafat Indonesia. 4 (2):186-194. 
Sa'diyah H., Candra I.D. 2020. Managing Social Innovation in Crowdfunding Digital Platform. Airlangga Journal of Innovation Management. 1 (1):59-76.

Sugiyono. (1997). Metodologi Penelitian Administrasi. Yogyakarta: CV Alfabeta.

Sugiyono. (2012). Memahami Penelitian Kualitatif”. Bandung: ALFABETA.

Sugiyono. (2017). Metode Penelitian Kuantitatif, Kualitatif, dan R\&D. Bandung: Alfabeta

Umar, Husein. (2013). Metode Penelitian untuk skripsi dan Tesis Bisnis. Jakarta: PT Raja Grafindo Persada.

Widyaningsih N., Triyanto. 2021. Tinjauan Filsafat Pengembangan Media Blog Dalam Pembelajaran Menulis Teks Anekdot Pada Siswa Kelas X SMA. Jurnal Education. 7 (3):662667.

Zulkarnain, W., Andini, S. 2020. Inkubator Bisnis Modern Berbasis I-Learning untuk Menciptakan Kreativitas Startup di Indonesia. Adimas: Adi Pengabdian kepada Masyarakat. 1(1):77-87. 